\title{
Selective induction of apoptosis in Philadelphia chromosome-positive chronic myelogenous leukemia cells by an inhibitor of BCR - ABL tyrosine kinase, CGP 57148
}

\author{
Shingo Dan ${ }^{1}$, Mikihiko Naito ${ }^{1}$ and Takashi Tsuruo ${ }^{1,2,3}$ \\ ${ }^{1}$ Institute of Molecular and Cellular Biosciences, The University of Tokyo, Tokyo \\ ${ }^{2}$ Cancer Chemotherapy Center, Japanese Foundation for Cancer Research, \\ Tokyo, Japan \\ ${ }^{3}$ corresponding author: Institute of Molecular and Cellular Biosciences, The \\ University of Tokyo, Yayoi, Bunkyo-ku, Tokyo 113, Japan. tel: 81-3-3818- \\ 5341; fax: 81-3-3816-3592; e-mail: ttsuruo@imcbns.iam.u-tokyo.ac.jp
}

Received 10.11.97; revised 6.3.98; accepted 2.4.98

Edited by: Y. Kuchino

\begin{abstract}
The BCR-ABL tyrosine kinase has been implicated as the cause of Philadelphia chromosome $\left(\mathrm{Ph}^{1}\right)$-positive leukemias. We report herein that CGP 57148, a selective inhibitor of the ABL tyrosine kinase, caused apoptosis specifically in bcrabl-positive chronic myelogenous leukemia (CML) cells, K562 and KYO-1. Upon treatment with CGP 57148, CRKL, a specific substrate for $B C R-A B L$ that propagates signals via phosphatidylinositol-3' kinase (PI3K), was dephosphorylated, indicating inhibition of BCR-ABL tyrosine kinase at the cellular level. Likewise, MAPK/ERK, a downstream mediator of Ras, was also dephosphorylated. Caspase activation and cleavage of retinoblastoma protein (pRB) accompanied the development of CGP 57148-induced apoptosis. Inhibition of caspase suppressed apoptosis and the cleavage of pRB, and in turn arrested cells in the $G_{1}$ phase. These results indicate that CGP 57148 shows apoptogenic and anti-proliferative effects on bcr-abl-positive cells by blocking BCR-ABLinitiated signaling pathways.
\end{abstract}

Keywords: CML; BCR-ABL; apoptosis; K562; KYO-1

\begin{abstract}
Abbreviations: $\mathrm{CML}$, chronic myelogenous leukemia; $\mathrm{Ph}^{1}$, Philadelphia chromosome; PI3K, phosphatidylinositol-3' kinase; MAPK, mitogen-activated protein kinase; ERK, extracellular signalregulated kinase; $p R B$, retinoblastoma protein; TNF, tumor necrosis factor; Z-Asp, benzyloxycarbonyl-Asp- $\mathrm{CH}_{2} \mathrm{OC}(\mathrm{O})$-2,6-dichlorobenzene; ICE, interleukin $1 \beta$-converting enzyme; AMC, 7-amino4-methylcoumarin
\end{abstract}

\section{Introduction}

Chronic myelogenous leukemia $(\mathrm{CML})$ is a malignant disease of a pluripotent hematopoietic stem cell and is characterized by excessive proliferation of the myeloid lineage. The hallmark of $\mathrm{CML}$ is the Philadelphia chromosome $\left(\mathrm{Ph}^{1}\right)$, which is detected in virtually all cases. It is formed by a translocation between chromosome 9 and 22 (de Klein et al, 1982; Heisterkamp et al, 1983). This translocation results in a production of the $\mathrm{BCR}-\mathrm{ABL}$ fusion protein with enhanced tyrosine kinase activity, which is a major factor in the pathophysiology of CML (Heisterkamp et al, 1985; 1990).

The BCR-ABL tyrosine kinase phosphorylates cellular proteins such as CRKL and CBL (Andoniou et al, 1994; Nichols et al, 1994; Oda et al, 1994). The phosphorylated $\mathrm{CRKL}$ and $\mathrm{CBL}$ form a stable complex including BCR-ABL and phosphatidylinositol-3' kinase (PI3K) (Sattler et al, 1996), which in turn activates PI3K to promote cell proliferation (Skorski et al, 1995). BCR-ABL is also shown to activate Ras-dependent signaling pathways (Pendergast et al, 1993). The activated Ras is involved in an anti-apoptotic and proliferative signal initiated by BCRABL (Cortez et al, 1996).

Since $B C R-A B L$ plays a key role in transforming cells in $\mathrm{CML}$ patients, treatment with a selective inhibitor of the $\mathrm{BCR}-\mathrm{ABL}$ tyrosine kinase could be a promising therapeutic approach to this disease. One of the most selective and potent inhibitors of $\mathrm{BCR}-\mathrm{ABL}$ tyrosine kinase is CGP 57148 (Buchdunger et al, 1996). This compound specifically inhibits cellular proliferation of $\mathrm{Ph}^{1}$-positive $\mathrm{K} 562$ cells in vitro and tumor formation by $\mathrm{BCR}-\mathrm{ABL}$-expressing cells in vivo (Druker et al, 1996). Because BCR-ABL tyrosine kinase shows the anti-apoptotic activity in $\mathrm{CML}$ cells, we postulated that CGP 57148 could induce apoptosis in $\mathrm{Ph}^{1}$ positive CML cells. We report herein that CGP 57148 selectively induces cell death via apoptosis in $\mathrm{Ph}^{1}$-positive CML cell lines, K562 and KYO-1, but not in such $\mathrm{Ph}^{1}$ negative cell lines as U937, THP-1 and HL-60. As we expected, CGP 57148 has potential as a therapeutic drug against $\mathrm{Ph}^{1}$-positive leukemias.

\section{Results}

\section{Selective induction of apoptosis in CML cells by CGP 57148}

The K562 cell line is known to be resistant to cell death via apoptosis, irrespective of the inducing agents. Figure 1a shows the morphologic changes in K562 and U937 cells after treatment with VP-16, adriamycin and CGP 57148. VP-16 and adriamycin, both clinically useful anticancer drugs, induced apoptotic morphologic changes in U937 cells but not in K562 cells. However, treating the cells with $10 \mu \mathrm{M}$ CGP 57148 for $48 \mathrm{~h}$ caused apoptotic changes in $\mathrm{K} 562$ cells, but not in U937 cells. Figure $1 \mathrm{~b}$ shows the flow-cytometric analysis of the cells treated with CGP 57148. The subdiploid population of K562 cells increased after $24 \mathrm{~h}$ and $48 \mathrm{~h}$ of treatment with CGP 
a

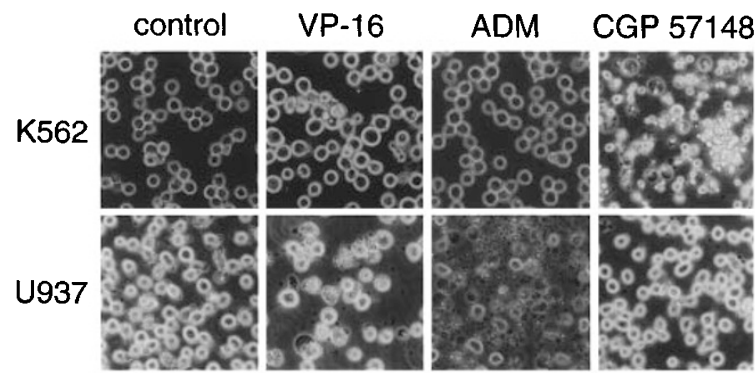

b

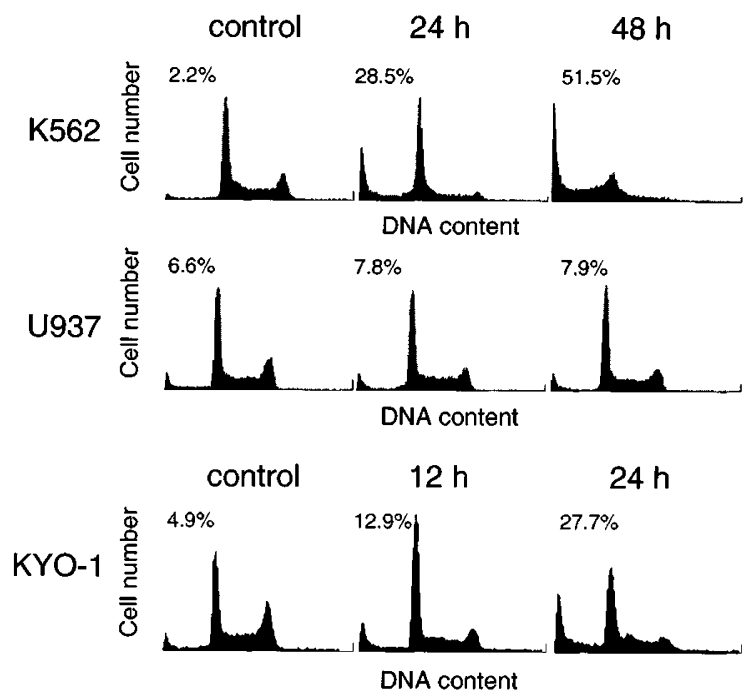

Figure 1 (a) Phase contrast micrographs of $\mathrm{K} 562$ and $\mathrm{U} 937$ cells treated with various anticancer agents ( $10 \mu \mathrm{g} / \mathrm{ml} \mathrm{VP-16}$ for $4 \mathrm{~h}, 0.5 \mu \mathrm{g} / \mathrm{ml}$ adriamycin (ADM) for $18 \mathrm{~h}$, and $10 \mu \mathrm{M}$ CGP 57148 for $48 \mathrm{~h}$ ). CGP 57148 induced blebbing of cell membrane and formation of apoptotic bodies in K562 but not in U937 cells. In contrast, K562 showed a much decreased susceptibility against VP-16 and adriamycin, compared with U937. (b) Flow cytometric analysis of K562, U937 and KYO- 1 cells treated with $10 \mu \mathrm{M}$ CGP 57148 for the indicated time. Indicated number in each FACS profile is the percentage of subdiploid cells

57148 , while no increase of the subdiploid cells was observed in U937 cells. The subdiploid cells were also observed upon treatment of CGP 57148 in another CML cell line, KYO-1.

To confirm that the cell death of $\mathrm{CML}$ cells triggered by CGP 57148 was due to apoptosis, DNA fragmentation assay was performed. The oligonucleosomal DNA ladder, which is one of the hallmarks of apoptosis, was observed in $\mathrm{K} 562$ cells and KYO-1 cells after $24 \mathrm{~h}$ of treatment with $10 \mu \mathrm{M}$ CGP 57148 (Figure 2a). We next examined the dose-dependent effect of CGP 57148. The DNA ladder was observed when $\mathrm{K} 562$ cells were treated with $0.3 \mu \mathrm{M}$ CGP 57148 or higher. Meanwhile, $\mathrm{Ph}^{1}$-negative leukemia cell lines, U937, HL-60 and THP-1, did not show DNA ladders, even if the cells were treated with $10 \mu \mathrm{M}$ CGP 57148 (Figure 2b). VP-16 caused DNA ladder to appear in U937, HL-60 and THP-1 but not in K562 cells (Figure 2c). Staurosporine, a potent inducer of apoptosis that selectively inhibits protein kinase $C$, could not induce apoptosis in K562 cells, either (Figure 2d). These results indicate that a

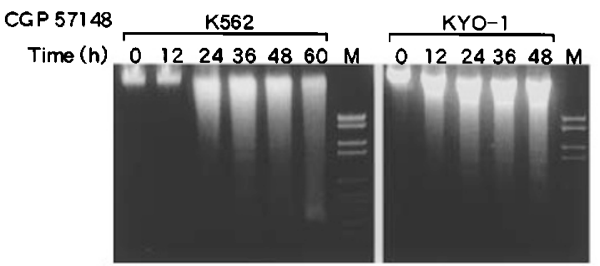

b

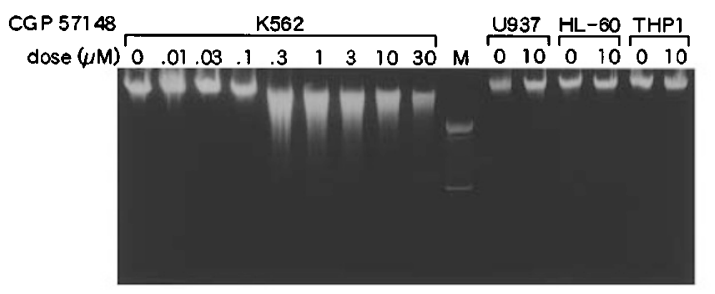

C
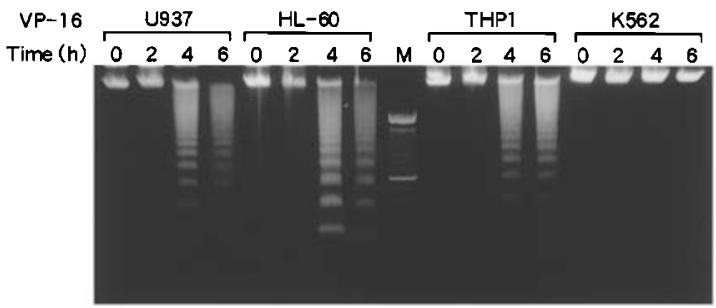

d

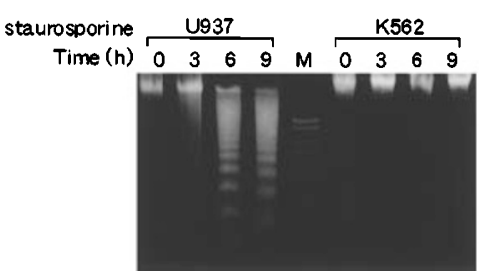

Figure 2 DNA fragmentation assay upon treatment with CGP 57148, VP-16 and staurosporine. (a) $\mathrm{K} 562$ cells $\left(2 \times 10^{5} \mathrm{cells} / \mathrm{ml}\right)$ and $\mathrm{KYO}-1$ cells $\left(1 \times 10^{5} \mathrm{cells} / \mathrm{ml}\right)$ were treated with $10 \mu \mathrm{M}$ CGP 57148 for the indicated time. Oligonucleosomal DNA ladder was observed within $24 \mathrm{~h}$ after treatment. (b) Dose dependence of CGP 57148 to trigger DNA fragmentation. K562 and other leukemic cell lines, U937, HL-60 and THP-1, were treated with CGP 57148 for $48 \mathrm{~h}$ at the indicated concentrations. (c) K562, U937, HL-60 and THP-1 cells were treated with $10 \mu \mathrm{g} / \mathrm{ml} \mathrm{VP-16}$ for the indicated time. (d) U937 and $\mathrm{K} 562$ cells were treated with $0.3 \mu \mathrm{g} / \mathrm{ml}$ staurosporine for the indicated time

CML cells undergo apoptosis upon CGP 57148 treatment but not upon treatment with other anticancer drugs.

\section{Inhibition of BCR-ABL tyrosine kinase at the cellular level}

The transformation and cellular proliferation due to BCR$A B L$ was shown to be mediated via both Ras- and PI3Kdependent signaling pathways. CGP 57148 is a selective inhibitor of $\mathrm{ABL}$ tyrosine kinase and would be expected to inhibit the growth signals initiated by $B C R-A B L$ by blocking its kinase activity. To determine if CGP 57148 inhibits tyrosine kinase activity of $B C R-A B L$ at the cellular level, we analyzed the phosphorylation of a CRKL protein, which is a major substrate of $B C R-A B L$ tyrosine kinase and is involved in the PI3K-dependent signaling pathway (Figure 3). The upper band represents the tyrosine phosphorylated form of CRKL. 
The amount of phosphorylated protein band was reduced upon treatment with $0.3 \mu \mathrm{M}$ CGP 57148 ; at this concentration, apoptosis could be induced (Figure $2 b$ ). The band completely dissapeared when cells were treated with $1 \mu \mathrm{M}$ CGP 57148 or higher. The result indicates that CGP 57148 effectively inhibited BCR-ABL tyrosine kinase activity in K562 cells at the cellular level.

We further examined the phosphorylation of the mitogen-activated protein kinase/extracellular signal-regulated kinase (MAPK/ERK), a downstream mediator of the Ras-dependent signaling cascade (Figure 4). Although CGP 57148 treatment did not affect the amount of MAPK/ ERK, it did diminish the amount of phosphorylated MAPK/ ERK in a dose-dependent manner. In effect, the phosphorylated form of MAPK/ERK vanished when cells were treated with $0.3 \mu \mathrm{M}$ CGP 57148 or higher. These results suggested that both $\mathrm{PIOK}$ - and Ras-dependent signaling pathways intiated by $B C R-A B L$ were blocked by CGP 57148.

\section{Caspase activation by CGP 57148}

In most cell systems, caspase activation accompanies the development of apoptosis (Martin and Green, 1995; Vaux and Strasser, 1996). Therefore, we examined the cleavage activity of DEVD-MCA, a fluorogenic substrate specific to caspase-3 (CPP32/Yama/Apopain) (Mashima et al, 1995a), during the course of K562 apoptosis initiated by CGP 57148 (Figure 5a). The DEVD - MCA cleavage activity greatly increased in CGP 57148-treated K562 cells, in accordance with the apoptosis development. U937 and THP-1 treated with CGP 57148 did not show the DEVD - MCA cleavage activity. In contrast, VP16 induced cleavage activity in U937 and THP-1 cells but not in K562 cells (Figure 5b). These results indicate that caspase

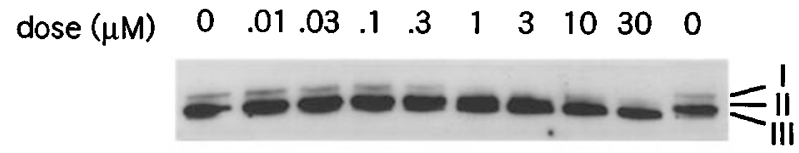

Figure 3 Western blot analysis of the CRKL protein, a major substrate of BCR-ABL. K562 cells were treated with CGP 57148 at the indicated concentrations for $24 \mathrm{~h}$. Lysate was prepared from each sample and immunoblotted with anti-CRKL antibody. The highest molecular weight species designated 'l', or the tyrosine phosphorylated form of CRKL, declined in a dose-dependent manner

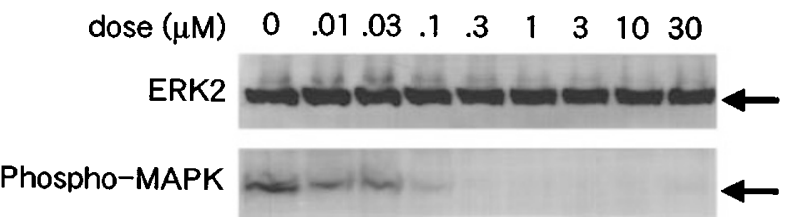

Figure 4 Inactivation of MAPK/ERK upon treatment of CGP 57148 in K562 cells. K562 cells were treated with CGP 57148 at the indicated concentrations for $24 \mathrm{~h}$. Total cell lysate was prepared and immunoblotted with anti-ERK2 (upper panel) and anti-phospho-specific MAP kinase antibody (lower panel) The phosphorylated active form of MAPK/ERK declined in a dose-dependent manner. activation accompanies the development of K562 apoptosis induced by CGP 57148 .

We next examined the effect of Z-Asp- $\mathrm{CH}_{2}$-DCB (Z-Asp), a specific caspase inhibitor, on CGP 57148-induced apoptosis of K562 cells and found that it effectively suppressed formation of apoptotic bodies. Meanwhile, the co-treated cells were smaller than the untreated or Z-Asptreated K562 cells, suggesting that the cell cycle progression was disturbed (Figure 6a). Therefore, we used flow cytometry to examine the effect of Z-Asp on the cell cycle progression. K562 cells treated with CGP 57148 alone showed a substantial population of subdiploid cells, indicating the development of apoptosis. On the other hand, the cells treated with CGP 57148 and Z-Asp accumulated in the $\mathrm{G}_{1}$ phase, and the emergence of subdiploid cells was suppressed. Z-Asp alone had no effect on the cell cycle distribution of K562 cells (Figure 6b). These results indicate that Z-Asp inhibits CGP 57148-induced apoptosis of K562 cells, which results in the $\mathrm{G}_{1}$ arrest of $\mathrm{K} 562$ cells.

\section{a CGP 57148}

$$
\text { b VP-16 }
$$

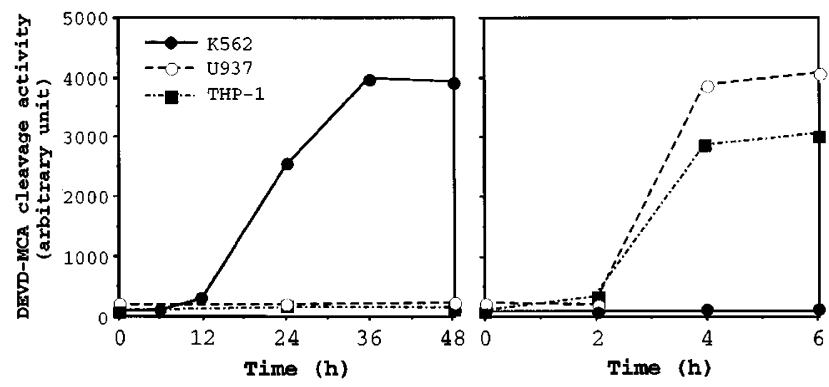

Figure 5 Elevation of cleavage activity of DEVD-MCA, a specific substrate for caspase-3. K562 (closed circles), U937 (open circles) and THP-1 (closed squares) were treated with $10 \mu \mathrm{M}$ CGP 57148 (a) or $10 \mu \mathrm{g} / \mathrm{ml} \mathrm{VP-16} \mathrm{(b)} \mathrm{for} \mathrm{the}$ indicated time. Cell extract corresponding $10 \mu \mathrm{g}$ was used for the DEVD-MCA assay

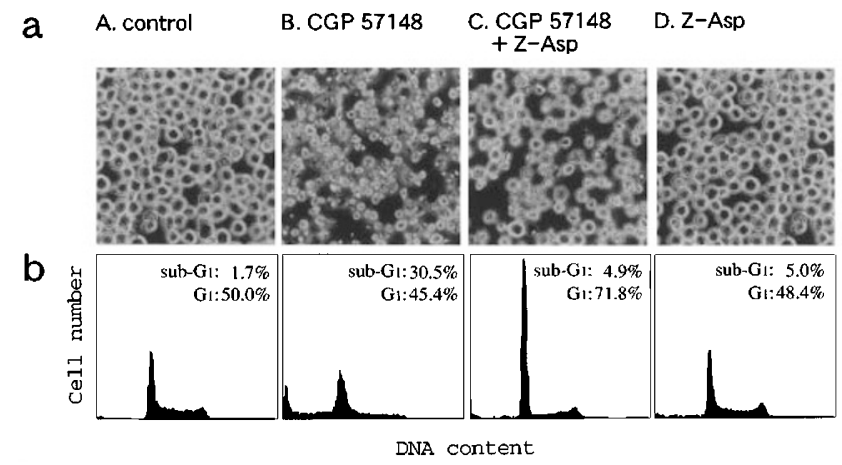

Figure 6 Phase contrast micrographs (a) and flow cytometric analysis (b) of K562 cells treated with DMSO (A), $10 \mu \mathrm{M}$ CGP 57148 (B), $10 \mu \mathrm{M}$ CGP 57148 and $100 \mu \mathrm{g} / \mathrm{ml}$ Z-Asp-CH - -DCB (Z-Asp) (C), and Z-Asp alone (D) for $36 \mathrm{~h}$. The indicated numbers are the percentages of apoptotic subdiploid cells (sub- $\left.G_{1}\right)$ and cells in the $G_{1}$ phase of cell cycle $\left(G_{1}\right)$, respectively. Z-Asp suppressed the formation of apoptotic bodies induced by CGP 57148 treatment, and in turn, arrested cells in the $G_{1}$ phase 


\section{pRB dephosphorylation and cleavage}

Recent studies demonstrated that phosphorylation of the retinoblastoma protein ( $p R B$ ) regulates $G_{1} / S$ transition in cell cycle progression. In addition, $\mathrm{pRB}$ is cleaved during apoptosis development (An and Dou, 1996; Janicke et al, 1996). Therefore, we examined the phosphorylation and cleavage of pRB in K562 cells treated with CGP 57148 and ZAsp (Figure 7). In the untreated or the Z-Asp-treated K562 cells, the majority of $p R B$ was hyperphosphorylated. When K562 cells were co-treated with CGP 57148 and Z-Asp, the hyperphosphorylated $\mathrm{pRB}$ band shifted to the hypophosphorylated band in a time-dependent manner, concomitant with the cell cycle arrest in $\mathrm{G}_{1}$ phase. In $\mathrm{K} 562$ cells treated with CGP 57148 alone, the hypophosphorylated pRB also appeared in a time-dependent manner. After 36 and $48 \mathrm{~h}$, pRB was cleaved to generate p48 and p30 fragments, and the intact $\mathrm{pRB}$ band reciprocally disappeared. These results suggest that Z-Asp prevents the cleavage of $p R B$, leaving the hypophosphorylated form of $\mathrm{pRB}$ and consequently inhibits the entry of CGP 57148 -treated $\mathrm{K} 562$ cells from $\mathrm{G}_{1}$ into $\mathrm{S}$ phase.

\section{Discussion}

$\mathrm{BCR}-\mathrm{ABL}$ tyrosine kinase plays a central role in tumorigenesis of CML cells. Almost all CML patients exibit the $\mathrm{Ph}^{1}$ chromosome, which generates the expression of the BCR$A B L$ fusion gene. When expressed in hematopoietic cells, the BCR-ABL causes cytokine-independent proliferation, induces tumorigenic growth and prevents apoptosis in response to cytokine deprivation or DNA damage (McGahon et al, 1994). Therefore, a therapeutic approach targeting the BCR-ABL could hold promise as a treatment modality for CML. In fact, CGP 57148, an inhibitor of $\mathrm{BCR}-\mathrm{ABL}$ tyrosine kinase, selectively inhibits tumor formation and cellular proliferation by $\mathrm{BCR}-\mathrm{ABL}$-expressing cells in vitro and in vivo (Buchdunger et al, 1996). Moreover, human megakaryocytic MO7 cells and murine factor-dependent 32D cells transformed with $B C R-A B L$ resulted in cell death upon treatment of CGP 57148, while no inhibition of proliferation was

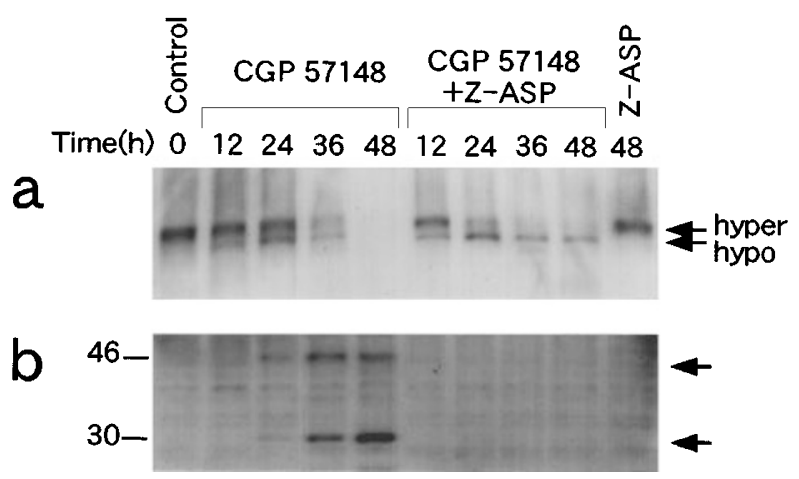

Figure 7 Western blot analysis of pRB. K562 cells were continuously treated with $10 \mu \mathrm{M}$ CGP 57148 and/or $100 \mu \mathrm{g} / \mathrm{ml} \mathrm{Z-Asp-CH}$-DCB (Z-Asp) for the indicated time. Total cell lysate was prepared from each sample and electrophoresed in a $7.5 \%$ (a) or $4-20 \%$ gradient (b) SDS-polyacrylamide gel and immunoblotted with anti-pRB antibody observed in their parental cell lines (Buchdunger et al, 1996). Since BCR-ABL shows anti-apoptotic activity, we assume that CGP 57148 causes apoptosis of BCR-ABLexpressing cells. We demonstrated by morphological and biochemical studies that the cell death of BCR-ABLexpressing cells by CGP 57148 is due to apoptosis by using two distinct $\mathrm{BCR}-\mathrm{ABL}$-expressing $\mathrm{CML}$ cells, K562 and KYO-1. Since the ability of CGP 57148 to induce growth arrest and apoptosis is highly selective to $B C R-A B L$-expressing cells, this compound could be a selective drug without serious cytotoxicity to normal cells.

The molecular mechanism of $\mathrm{BCR}-\mathrm{ABL}$ in tumorigenesis has been well studied. One of the signaling pathways initiated by $B C R-A B L$ is a Ras-dependent signaling cascade. BCR$A B L$ was shown to elevate the ratio of the guanosine triphosphate (GTP)-bound active form of Ras p21 (Mandanas et al, 1993). This pathway was reported to be involved in tumorigenic growth and apoptosis prevention (Cortez et al, 1996). Another signaling pathway is PI3K, which promotes cellular proliferation. $\mathrm{BCR}-\mathrm{ABL}$ has been suggested to induce the formation of multimeric complexes of signalling proteins, which include CBL, PI3K, CRKL and BCR-ABL itself, and activate PI3K activity in a BCR-ABL tyrosine kinase-dependent manner (Sattler et al, 1996). Furthermore, the selective PI3K inhibitor wortmannin, or antisense oligonucleotides against PI3K p85, abolishes cellular proliferation of bcr-abl-positive cells (Skorski et al, 1995). In this study, inhibition of $B C R-A B L$ tyrosine kinase by CGP 57148 resulted in dephosphorylation of CRKL and MAPK/ ERK, involved in the signaling pathways via PI3K and Ras, respectively. Furthermore, the dephosphorylation of these proteins correlated well with the incidence of CGP 57148induced apoptosis. These results suggest that CGP 57148 inhibited both signals via Ras and PI3K, which were initiated by $B C R-A B L$ tyrosine kinase, and consequently triggered apoptosis of $b c r-a b l$-positive cells.

Like apoptosis development in other cellular systems, caspase-3-like activity increased during CGP 57148induced apoptosis of BCR-ABL-positive K562 cells. Cotreatment with the caspase inhibitor Z-Asp inhibited the CGP 57148-induced apoptosis and arrested the cells in the $\mathrm{G}_{1}$ phase. Furthermore, the $\mathrm{G}_{1}$ arrest coincided with hypophosphorylation of pRB, which controls the $\mathrm{G}_{1} / \mathrm{S}$ transition. When $\mathrm{K} 562$ cells were treated with CGP 57148 alone, pRB was cleaved into fragments. Inversely, the fragmentation of $\mathrm{pRB}$ is probably mediated by a caspase(s) since the cleavage was suppressed by the caspase inhibitor Z-Asp. An and Dou reported that $\mathrm{pRB}$ was cleaved into at least two fragments, p68 and p48, during apoptosis (An and Dou, 1996). In our study, p30 fragment was detected along with p48, which indicated pRB was cleaved into at least three fragments during K562 apoptosis initiated by CGP 57148. The roles of the dephosphorylation and $\mathrm{pRB}$ cleavage in apoptosis are not yet clear, but pRB has been shown to suppress apoptosis in some cellular systems (Berry et al, 1996; McConkey et al, 1996; Wang et al, 1997). Therefore, the fragmentation of pRB is probably involved in converting the arrested cells to apoptotic cells. These observations indicate that CGP 57148 causes antiproliferative as well as apoptogenic activity in K562 cells. 
These effects of CGP 57148 on $\mathrm{Ph}^{1}$-positive $\mathrm{K} 562$ cells that trigger apoptosis or $\mathrm{G}_{1}$ arrest could be explained by the molecular function of $\mathrm{BCR}-\mathrm{ABL}$ tyrosine kinase and its inhibition by CGP 57148, as described above. However, we can not rule out that CGP 57148 has some other functions distinct from $B C R-A B L$ inhibition, which are involved in the apoptosis development of $B C R-A B L$ positive cells. In particular, it is still unclear whether the activation of caspase- 3 is dependent on the inhibition of BCR-ABL tyrosine kinase activity by this compound. Further studies are needed to clarify the molecular mechanism of CGP 57148 , a selective anticancer drug for treating CML.

\section{Materials and Methods}

\section{Materials}

CGP 57148B (the methane sulfonate salt of CGP 57148) was obtained from Novartis Pharma Inc., Basel, Switzerland. A stock solution of CGP 57148B was prepared at a concentration of $10 \mathrm{mM}$ by dissolving the compound in sterile phosphate-buffered saline (PBS) or dimethylsulfoxide (DMSO). VP-16 and adriamycin were kindly provided from Bristol-Myers Squibb Co., Ltd (Tokyo, Japan) and Kyowa Hakko Kogyo (Tokyo, Japan), respectively. Staurosporine was obtained from Sigma Chemical Co. (St. Louis, MO). Z-Asp-CH $-\mathrm{CH}_{2}-\mathrm{DCB}$ was obtained from Funakoshi (Tokyo, Japan). The antibody against CRKL (C-20) and anti-ERK2 were obtained from Santa Cruz Biotechnology, Inc. (Santa Cruz, CA). Anti-phospho-specific MAP kinase antibody was obtained from New England Biolabs, Inc. (Beverly, MA). The pRB antibody (G3-245) was purchased from Pharmingen (San Diego, CA).

\section{Cell lines and cell culture}

Chronic myelogenous leukemia cell lines, K562 and KYO-1, and other human leukemic cell lines, U937, HL-60, and THP-1, were grown in RPMI 1640 medium (Nissui Co., Ltd., Tokyo, Japan) supplemented with $10 \%$ heat inactivated fetal bovine serum and $100 \mu \mathrm{g} / \mathrm{ml}$ kanamycin in a humidified atmosphere of $5 \% \mathrm{CO}_{2}$ and $95 \%$ air at $37^{\circ} \mathrm{C}$. All the experiments were carried out using cells in their exponential growth phase and were repeated at least three times.

\section{DNA fragmentation assay}

Cells were harvested and treated with proteinase $K$ and RNase $A$, as previously described (Fujita et al, 1993). The resulting DNA was electrophoresed in an agarose gel and visualized by staining with ethidium bromide.

\section{DEVD - MCA cleavage assay (AMC assay)}

Cells were harvested and cell extracts were prepared, as described (Mashima et al, 1995b). Briefly, $10 \mu \mathrm{g}$ of cytosolic fraction from each sample was mixed in $50 \mu$ l of ICE buffer containing 20 mM HEPES$\mathrm{NaOH}$ (pH 7.5), $2 \mathrm{mM}$ dithiothreitol, $10 \% \mathrm{v} / \mathrm{v}$ glycerol and $1 \mathrm{mM}$ DEVD-MCA (Peptide Institute, Osaka, Japan) as a substrate (Noguchi et al, 1996). The reaction mixture was incubated at $37^{\circ} \mathrm{C}$ for $30 \mathrm{~min}$ and increase in the AMC fluorescence was measured using a Hitachi F-2000 fluorometer ( $\lambda \mathrm{ex}=380 \mathrm{~nm}, \lambda \mathrm{em}=460 \mathrm{~nm}$ ).

\section{FACScan analysis of cell cycle distribution}

Cells were harvested, washed with PBS and fixed in $70 \%$ ethanol, as previously described (Naito et al, 1997). The fixed cells were washed with PBS and resuspended in $1 \mathrm{mg} / \mathrm{ml}$ ribonuclease A in PBS, followed by incubation at $37^{\circ} \mathrm{C}$ for $30 \mathrm{~min}$. Cells were stained in $\mathrm{PI}$ solution $(50 \mu \mathrm{g} / \mathrm{ml}$ propidium iodide, $0.1 \%$ sodium citrate, $0.1 \%$ Nonidet P-40) and analyzed by using a Becton Dickinson FACScan flow-cytometer with Cell Quest software (Braintree, MA).

\section{Preparation of cell extracts and Western blotting}

Total extract was prepared, as described elsewere (Tomida et al, 1996). In brief, cells were harvested, and washed with PBS. The cell pellet was resuspended in $1 \times$ SDS sample buffer $(10 \% \mathrm{v} / \mathrm{v}$ glycerol, $5 \%$ 2-mercaptoethanol, $2 \%$ sodium dodecyl sulfate (SDS), $62.5 \mathrm{mM}$ Tris- $\mathrm{HCl} \mathrm{pH} \mathrm{6.8)} \mathrm{and} \mathrm{boiled} \mathrm{for} 5 \mathrm{~min}$. The protein assay was carried out using a BIO-RAD protein assay kit. Equal amounts of protein were subjected to SDS-polyacrylamide gel electrophoresis (SDS-PAGE) and transferred onto a nitrocellulose membrane (Schleider \& Schuell, Dassel, Germany). The membrane was incubated with primary antibody indicated in each experiment. Detection was accomplished using an appropriate anti-mouse or rabbit immunoglobulin secondary antibody and the enhanced chemiluminescence detection system (Amersham Japan, Ltd., Tokyo, Japan).

\section{Acknowledgements}

We are grateful to Novartis Pharma, Inc., for providing us CGP 57148 and to Dr. T. Mashima for helpful discussions. This work was supported by a special grant for Advanced Research on Cancer from the Ministry of Education, Science and Culture, and the Vehicle Racing Commemorative Foundation, Japan.

\section{References}

An B and Dou QP (1996) Cleavage of retinoblastoma protein during apoptosis: an interleukin $1 \beta$-converting enzyme-like protease as candidate. Cancer Res. 56: $438-442$

Andoniou CE, Thien CB, and Langdon WY (1994) Tumour induction by activated abl involves tyrosine phosphorylation of the product of the cbl oncogene. EMBO J. 13: $4515-4523$

Berry DE, Lu Y, Schmidt B, Fallon PG, O'Connell C, Hu SX, Xu HJ and Blanck G (1996) Retinoblastoma protein inhibits IFN- $\gamma$-induced apoptosis. Oncogene 12: 1809- 1819

Buchdunger E, Zimmermann J, Mett H, Meyer T, Muller M, Druker BJ and Lydon NB (1996) Inhibition of the Abl protein-tyrosine kinase in vitro and in vivo by a 2phenylaminopyrimidine derivative. Cancer Res. 56: 100-104

Cortez D, Stoica G, Pierce JH and Pendergast AM (1996) The BCR-ABL tyrosine kinase inhibits apoptosis by activating a Ras-dependent signaling pathway. Oncogene 13: 2589-2594

de Klein A, van Kessel AG, Grosveld G, Bartram CR, Hagemeijer A, BootsmaD, Spurr NK, Heisterkamp N, Groffen J and Stephenson JR (1982) A cellular oncogene is translocated to the Philadelphia chromosome in chronic myelocytic leukaemia. Nature 300: 765-767

Druker BJ, Tamura S, Buchdunger E, Ohno S, Segal GM, Fanning S, Zimmermann J and Lydon NB (1996) Effects of a selective inhibitor of the Abl tyrosine kinase on the growth of Bcr-Abl positive cells. Nat. Med. 2: 561-566

Fujita N, Kataoka S, Naito M, Heike Y, Boku N, Nakajima M and Tsuruo T (1993) Suppression of T-lymphoma cell apoptosis by monoclonal antibodies raised against cell surface adhesion molecules. Cancer Res. 53: 50225027

Heisterkamp N, Jenster G, ten Hoeve J, Zovich D, Pattengale PK and Groffen $J$ (1990) Acute leukaemia in bcr/abl transgenic mice. Nature 344: $251-$ 253 
Heisterkamp N, Stam K, Groffen J, de Klein A and Grosveld G (1985) Structural organization of the bcr gene and its role in the $\mathrm{Ph}^{1}$ translocation. Nature 315 : $758-761$

Heisterkamp N, Stephenson JR, Groffen J, Hansen PF, de Klein A, Bartram CR and Grosveld G (1983) Localization of the c-abl oncogene adjacent to a translocation break point in chronic myelocytic leukaemia. Nature 306: 239-242

Janicke RU, Walker PA, Lin XY and Porter AG (1996) Specific cleavage of the retinoblastoma protein by an ICE-like protease in apoptosis. EMBO J. 15:6969 6978

Mandanas RA, Leibowitz DS, Gharehbaghi K, Tauchi T, Burgess GS, Miyazawa K, Jayaram HN and Boswell HS (1993) Role of p21 RAS in p210 bcr-abl transformation of murine myeloid cells. Blood 82: 1838-1847

Martin SJ and Green DR (1995) Protease activation during apoptosis: death by a thousand cuts? Cell 82: 349-352

Mashima T, Naito M, Kataoka S, Kawai H and Tsuruo T (1995a) Aspartate-based inhibitor of interleukin- $1 \beta$-converting enzyme prevents antitumor agent-induced apoptosis in human myeloid leukemia U937 cells. Biochem. Biophys. Res. Commun. 209: $907-915$

Mashima T, Naito M, Fujita N, Noguchi K and Tsuruo T (1995b) Identification of actin as a substrate of ICE and an ICE-like protease and involvement of an ICE-like protease but not ICE in VP-16-induced U937 apoptosis. Biochem. Biophys. Res. Commun. 217: 1185-1192

McConkey DJ, Goodrich D, Bucana C and Klostergaard J (1996) The human retinoblastoma gene product suppresses ceramide-induced apoptosis in human bladder tumor cells. Oncogene 13: 1693-1700

McGahon A, Bissonnette R, Schmitt M, Cotter KM, Green DR and Cotter TG (1994) BCR-ABL maintains resistance of chronic myelogenous leukemia cells to apoptotic cell death. Blood 83: 1179-1187

Naito M, Nagashima K, Mashima T and Tsuruo T (1997) Phosphatidylserine externalization is a downstream event of interleukin- $1 \beta$-converting enzyme family protease activation during apoptosis. Blood 89: 2060-2066
Nichols GL, Raines MA, Vera JC, Lacomis L, Tempst P and Golde DW (1994) Identification of CRKL as the constitutively phosphorylated 39-kD tyrosine phosphoprotein in chronic myelogenous leukemia cells. Blood 84: 2912-2918

Noguchi K, Naito M, Oshimura M, Mashima T, Fujita N, Yonehara S and Tsuruo T (1996) Chromosome 22 complements apoptosis in Fas-and TNF-resistant mutant UK110 cells. Oncogene 13: 39-46

Oda T, Heaney C, Hagopian JR, Okuda K, Griffin JD and Druker BJ (1994) Crkl is the major tyrosine-phosphorylated protein in neutrophils from patients with chronic myelogenous leukemia. J. Biol. Chem. 269: 22925-22928

Pendergast AM, Quilliam LA, Cripe LD, Bassing CH, Dai Z, Li N, Batzer A, Rabun KM, Der CJ, Schlessinger J et al. (1993) BCR-ABL-induced oncogenesis is mediated by direct interaction with the $\mathrm{SH} 2$ domain of the GRB-2 adaptor protein. Cell 75 $175-185$

Sattler M, Salgia R, Okuda K, Uemura N, Durstin MA, Pisick E, Xu G, Li JL, Prasad KV and Griffin JD (1996) The proto-oncogene product p120CBL and the adaptor proteins CRKL and c-CRK link c-ABL, p190BCR/ABL and p210BCR/ABL to the phosphatidylinositol-3' kinase pathway. Oncogene 12: 839-846

Skorski T, Kanakaraj P, Nieborowska-Skorska M, Ratajczak MZ, Wen SC, Zon G, Gewirtz AM, Perussia B and Calabretta B (1995) Phosphatidylinositol-3 kinase activity is regulated by $B C R / A B L$ and is required for the growth of Philadelphia chromosome-positive cells. Blood 86: 726-736

Tomida A, Suzuki H, Kim HD and Tsuruo T (1996) Glucose-regulated stresses cause decreased expression of cyclin D1 and hypophosphorylation of retinoblastoma protein in human cancer cells. Oncogene 13: 2699-2705

Vaux DL and Strasser A (1996) The molecular biology of apoptosis. Proc. Natl. Acad. Sci. USA 93: 2239-2244

Wang J, Guo K, Wills KN and Walsh K (1997) Rb functions to inhibit apoptosis during myocyte differentiation. Cancer Res. 57: 351-354 